Pak. j. sci. ind. res. Ser. B: biol. sci. 201558 (2) 77-82

\title{
Nutrients Dynamics of Co-composting Poultry Litter with Fast Food Wastes
}

\author{
Asim Hayat ${ }^{\mathrm{a} *}$, Arshad Nawaz Chaudhary ${ }^{\mathrm{b}}$, Fayyaz Hussaina, Tanveer Iqbal ${ }^{\mathrm{b}}$, \\ Vishandas Suthar ${ }^{\mathrm{a}}$, Sana Ullah Jalil ${ }^{\mathrm{c}}$ and Zeshan Alid \\ ${ }^{a}$ Land Resource Research Institute, National Agricultural Research Centre (NARC), Park Road, Islamabad, Pakistan \\ ${ }^{b}$ Department of Soil Science \& SWC, Pir Mehr Ali Shah Arid Agriculture University, Rawalpindi, Pakistan \\ ${ }^{c}$ Rice Research Programme, National Agricultural Research Centre (NARC), Park Road, Islamabad, Pakistan \\ ${ }^{d}$ Ecotoxicology Research Institute, National Agricultural Research Center (NARC), Park Road, Islamabad, Pakistan
}

(received July 7, 2014; revised December 26, 2014; accepted December 29, 2014)

\begin{abstract}
Co-composting of poultry litter (PL) and fast food waste (FFW) in different combinations was carried out to explore the nutrient dynamics. The PL and FFW were co-composted in pits of dimensions $2 \mathrm{~m} \times 2 \mathrm{~m} \times 1.5 \mathrm{~m}(\mathrm{~L} \times \mathrm{W} \times \mathrm{D})$ in ratios of 100:0, 75:25, 50:50, 25:75 and 0:100, respectively, for a period of 105 days. Co-composts of PL and FFW in a 50:50 ratio yielded highest total nitrogen (3.63\%), total phosphorus $(0.81 \%)$, and total potassium (3.40\%) levels in the mature compost after 105 days of composting period. Carbon to nitrogen ratio for this combination was 18.33, which is suitable for safe land application. Present study identified PL and FFW co-composting in equal proportions yields maximum N, P and K levels with suitable $\mathrm{C}: \mathrm{N}$ ratio which may be applied to soils to meet crop nutrient demands and enhanced agricultural productivity.
\end{abstract}

Keywords: co-composting, poultry litter, fast food waste, total nitrogen, total phosphorus, C:N ratio

\section{Introduction}

Agriculture sector in Pakistan is facing an ever increasing pressure to meet food and fibre requirements of rapidly growing population, which currently stands at 180 million (Ali et al., 2013a). To ensure food security for continuously expanding population, crop productivity has become the ultimate goal of the farming communities. To achieve desired crop production, application of municipal/industrial effluents, sewage sludge, municipal solid wastes and excess pesticides/fertilisers usage in agricultural soils has become a custom resulting in considerable deterioration of the soil ecosystems (Ali et al., 2013b). All these practices are believed to supply essential nutrients for plant growth. However deleterious effects to human and livestock health remain a pressing concern.

Composting of different agricultural and municipal wastes to supply nutrients to growing crops has a long scientific prowess linked with significant agricultural production (Iyengar and Bhave, 2006). Composting is increasingly considered a good way for recycling the surplus manure as a stabilised and sanitized end-product for agriculture (Chaudhry et al., 2013; Khan et al., 2003). The advantages of composted organic wastes to soil structure, fertility as well as plant growth have been increasingly accentuated in recent literature (Goyal *Author for correspondence; E-mail: asimsatti94@gmail.com et al., 2005; Esse et al., 2001). Addition of un-decomposed wastes or non-stabilised compost to agricultural land may lead to immobilisation of plant nutrients and cause phytotoxicity (Cambardella et al., 2003). Moreover, the waste physico-chemical characteristics may not always be appropriate for composting. For instance, high moisture contents in food waste, inappropriate $\mathrm{C}: \mathrm{N}$ ratio, imbalanced amount of plant nutrients, pathogens and foul smelling odours may result in long treatment time or low degradation efficiency (Chaudhry et al., 2013). Co-composting of different types of organic products together overcomes the drawbacks of composting a single material (Goyal et al., 2005). Co-composting is extensively practiced method for solid waste management, which recovers organic matter from organic wastes (Castaldi et al., 2008).

Different agricultural/non-agricultural wastes are generated in excess in rural and urban communities of Pakistan which can be harvested by the composting process to ensure sustainable nutrient supply to growing plants. In current times enormous generation of poultry litter (agricultural waste) and fast food wastes (municipal waste) has caused serious environmental issues in Pakistan. According to Economic Survey of Pakistan (ESP, 2010), poultry sector is growing at the rate of $15-20 \%$ per annum, which generates poultry litter in 
voluminous amounts. According to Chaudhry et al. (2013) and Khan et al. (2003) poultry litter is being used as fertiliser by the farmers and is considered a better organic fertiliser than the farmyard manure. On another side, the number of hotels, motels and fast food restaurants has increased many folds in the last decades. These hotels and fast food restaurants are producing tonnes of solid food waste every year, lacking proper disposal and presenting a great challenge to the scientific community.

Present research was therefore, carried out to investigate the co-composting of poultry litter with fast food wastes in different combinations to convert these biological wastes (poultry litter and fast food wastes) into useful nutrient rich composts for supplementing plant growth. Co-composting of poultry litter and fast food wastes is an economical and environment friendly use of these biological wastes (Ranalli et al., 2001). Co-composting offers safe disposal coupled with optimal nutrient supply to the growing plants via mature composts. Present research also describes nutrient output in detail in different combinations and best suitable combination that gives better performance at the end of the composting process. Findings of this study will help farmers and researchers in efficient exploitation of the selected wastes for plant production.

\section{Materials and Methods}

Composting process, sampling and preparation. Present experiment was carried out at Pir Mehr Ali Shah Arid Agriculture University, Rawalpindi, Pakistan. Co-composting of poultry litter with fast food wastes was carried out in the following five combinations; $\mathrm{T}_{1}=$ poultry litter + fast food waste $(100: 0), \mathrm{T}_{2}=$ poultry litter+fast food waste $(75: 25), \mathrm{T}_{3}=$ poultry litter+fast food waste (50:50), $\mathrm{T}_{4}=$ poultry litter + fast food waste $(25: 75)$ and $\mathrm{T}_{5}=$ poultry litter+fast food waste $(0: 100)$. Poultry litter used was in pure guano form. Both PL and FFW were collected from the nearest locations in Rawalpindi city.

Composting was carried out in pits having dimensions of $2 \times 2 \times 1.5$ meter $(\mathrm{L} \times \mathrm{W} \times \mathrm{D})$ for 105 days. Raw poultry litter and fast food waste was placed in pits for composting under natural conditions. To maintain aerobic conditions, composting material was thoroughly mixed after every 15 days. Approximately $60-70 \%$ of the moisture content was sustained in the composting pits to support composting processes optimally. Compost sample collection for nutrient analyses was done at an interval of 15 days i.e. 10, 15, 30, 45, 60, 75, 90 and 105 days (Chaudhry et al., 2013; Castaldi et al., 2008). Three random subsamples were collected from each pit (top, center and bottom) making a composite sample of $1 \mathrm{~kg}$ for physical and chemical characterisation of the compost. Samples were dried at $65{ }^{\circ} \mathrm{C}$ in hot air oven for $48 \mathrm{~h}$ followed by grinding and passing through $1 \mathrm{~mm}$ sieve. Processed samples were stored in labeled plastic bottles at room temperature until further analyses.

Physical and chemical analyses of compost. Total nitrogen in the compost samples was determined by Kjeldahl method (Bremner, 1996). For phosphorus and potassium compost samples were digested using the perchloric acid-nitric acid digestion mixture (Kuo, 1996). Phosphorus in the acid digests was analysed on spectrophotometer at a wavelength of $880 \mathrm{~nm}$ whereas, potassium was analysed on flame photometer. Total organic carbon content was determined using $\mathrm{K}_{2} \mathrm{Cr}_{2} \mathrm{O}_{7}$ as an oxidizing agent (Nelson and Sommer, 1982). Temperature and moisture contents were recorded after every 15 days interval. Temperature was randomly recorded from middle and bottom locations of the composting pits and averaged to get a mean temperature value.

Statistical analysis. Analysis of variance (ANOVA) was performed for the studied parameters using Statistix 8.1 and the means were compared using LSD tests at $5 \%$ probability level.

\section{Results and Discussion}

Temperature changes. Change in temperature at various stages of decomposition of poultry litter with fast food wastes is shown in Fig 1. During composting, the internal temperature of the compost pits remained below $50{ }^{\circ} \mathrm{C}$ for period of 45 days that increased to $60{ }^{\circ} \mathrm{C}$ at $60-75$ days of composting in all treatments. After attaining peak temperature of $60^{\circ} \mathrm{C}$, it began to decline to ambient level $\left(35^{\circ} \mathrm{C}\right)$ in all the treatments. Different combinations of PL and FFW co-composts showed very small difference in temperature at the beginning and at the end of the experiment except 50:50 ratio of PL and FFW co-composts in which temperature was $6-16{ }^{\circ} \mathrm{C}$ higher than other treatments. Increase in temperature can be attributed to elevated microbial activity at the thermophilic stage (Chaudhry et al., 2013; Zhang et al., 2003). This increased temperature is also responsible for killing pathogens in the composting material which otherwise can be harmful for soil and plant health (Chaudhry et al., 2013). 


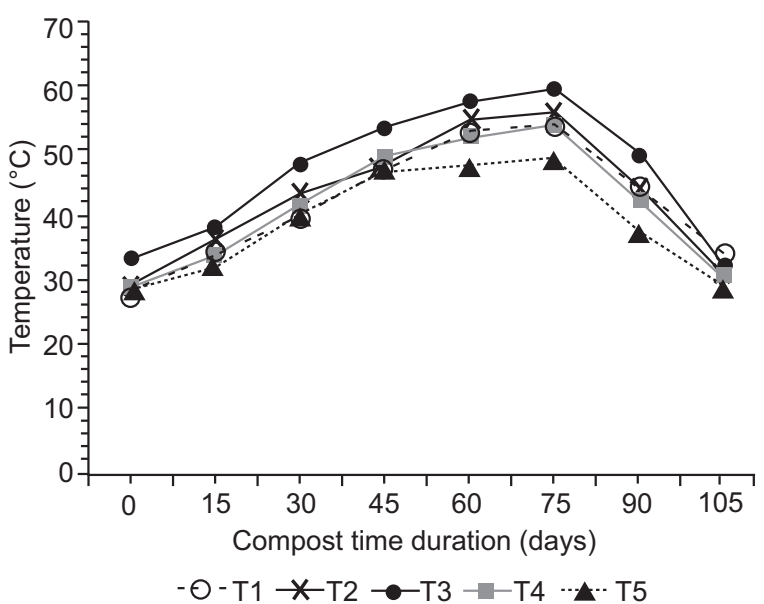

Fig. 1. Comparative effect of co-composting of poultry litter and fast food waste on temperature.

Carbon-nitrogen ratio (C:N). Data regarding carbon to nitrogen $(\mathrm{C}: \mathrm{N})$ ratio is shown in Table 1 . The $\mathrm{C}: \mathrm{N}$ ratio declined with the passage of time in all treatments due to the decomposition of carbohydrates which is a rich source of carbon. The availability of nitrogen also decreased with the increase in decomposition rate (Chaudhry et al., 2013; Adhikari et al., 2008; Benito et al., 2006). At the start of composting process the highest $\mathrm{C}: \mathrm{N}$ ratio (39.81) was observed in the treatment $\mathrm{T}_{5}$ and lowest was observed in $\mathrm{T}_{1}$ (25.36). In remaining treatments, at the initial stages, high $\mathrm{C}: \mathrm{N}$ ratios were observed, alike to $\mathrm{T}_{5}$. Maximum decreasing trend of C:N ratio i.e. from 38.78 to 18.33 was observed in the $\mathrm{T}_{3}$. Minimum C:N ratio (14.76) was observed in the treatment $\mathrm{T}_{1}$. Decrease in C:N ratio with increasing composting time is also supported by the results of Benito et al. (2006). Carbon to nitrogen ratio ranging from 12 to 20 is considered suitable for soil fertility and plant growth. From these results it can be inferred that the treatment $T_{3}$ gives promising decline in the $\mathrm{C}: \mathrm{N}$ ratio and proves to be the best combination investigated in this study for better crop production.

Nitrogen concentration increased due to the loss of dry weight as carbon dioxide and water during the mineralisation of organic matter. This correlates with the previous investigations of Alburquerque et al. (2006) regarding composting experiments. They concluded that due to the variation in carbon and nitrogen levels, the C:N ratio decreased during the composting process. They achieved a final C:N ratio of 14 at compost maturity.

Total nitrogen concentration. The data regarding nitrogen concentration in the co-composting process is depicted in Table 2. It was observed that the total nitrogen concentration increased with the composting time. Maximum nitrogen concentrations were recorded at 105 day in all the treatments. Maximum nitrogen concentration (3.38\%) was observed in treatment $\mathrm{T}_{3}$ having 50:50 percent poultry litter and fast food restaurant waste, however, minimum concentration $(1.70 \%)$ was recorded in treatment $T_{5}$. High nitrogen levels in $\mathrm{T}_{3}$ can be attributed to high mineralisation rates of composting material via microbial decomposition process whereas, lower $\mathrm{N}$ levels in $\mathrm{T}_{5}$ were due to slower microbial decomposition rate. In FFW initial carbon contents are generally higher however, initial $\mathrm{N}$ content were lower (Chang et al., 2006). These results are in accordance with the Rodriguez et al. (2003) who investigated co-composting of barley wastes and solid poultry waste revealing $3.56 \% \mathrm{~N}$ concentration at compost maturity. The results for low nitrogen concentrations in the treatment $\mathrm{T}_{5}$ with $100 \%$ fast food restaurant waste were similar with those reported by Chang et al. (2006) and Zhang et al. (2003).

Total phosphorus concentration. The data pertaining to concentration of total phosphorus is illustrated in

Table 1. Comparative effect of co-composting of poultry litter (PL) and fast food waste (FFW) on C:N ratio

\begin{tabular}{|c|c|c|c|c|c|c|c|c|c|}
\hline \multirow{2}{*}{$\begin{array}{l}\text { Treatment } \\
\text { (PL:FFW ratio) }\end{array}$} & \multicolumn{8}{|c|}{$\mathrm{C}: \mathrm{N}$ ratio (days) } & \multirow[t]{2}{*}{ Average } \\
\hline & 0 & 15 & 30 & 45 & 60 & 75 & 90 & 105 & \\
\hline $\mathrm{T}_{1}(100: 0)$ & 25.36 & 25.13 & 20.35 & 16.95 & 16.10 & 15.26 & 15.34 & 14.76 & $18.66^{\mathrm{e}}$ \\
\hline $\mathrm{T}_{2}(75: 25)$ & 35.44 & 34.15 & 25.59 & 26.05 & 19.73 & 17.76 & 17.15 & 16.47 & $24.04^{\mathrm{d}}$ \\
\hline $\mathrm{T}_{3}(50: 50)$ & 38.78 & 35.61 & 28.42 & 27.84 & 19.42 & 18.96 & 18.67 & 18.33 & $25.75^{\mathrm{c}}$ \\
\hline $\mathrm{T}_{4}(25: 75)$ & 36.31 & 33.61 & 29.89 & 25.65 & 24.42 & 23.60 & 22.63 & 22.48 & $27.32^{\mathrm{b}}$ \\
\hline $\mathrm{T}_{5}(0: 100)$ & 39.81 & 37.21 & 36.57 & 30.84 & 27.61 & 27.29 & 26.43 & 26.38 & $31.52^{\mathrm{a}}$ \\
\hline Days avg. & $35.14^{\mathrm{a}}$ & $33.146^{\mathrm{b}}$ & $28.16^{\mathrm{c}}$ & $25.47^{\mathrm{d}}$ & $21.47^{\mathrm{e}}$ & $20.57^{\mathrm{ef}}$ & $20.04^{\mathrm{f}}$ & $19.68^{f}$ & - \\
\hline
\end{tabular}

LSD value $(\mathrm{p}=0.05)$ : day*treatment $=2.741$; treatment $=0.969$; day $=1.226$. 
Table 2. Comparative effect of co-composting of PL and FFW on concentration of total nitrogen (\%)

\begin{tabular}{|c|c|c|c|c|c|c|c|c|c|}
\hline \multirow{2}{*}{$\begin{array}{l}\text { Treatment } \\
\text { (PL:FFW ratio) }\end{array}$} & \multicolumn{8}{|c|}{ Total N concentration (days) } & \multirow[t]{2}{*}{ Average } \\
\hline & 0 & 15 & 30 & 45 & 60 & 75 & 90 & 105 & \\
\hline $\mathrm{T}_{1}(100: 0)$ & 3.22 & 3.26 & 3.33 & 3.36 & 3.36 & 3.43 & 3.45 & 3.46 & $3.37^{\mathrm{a}}$ \\
\hline $\mathrm{T}_{2}(75: 25)$ & 2.83 & 2.84 & 2.96 & 3.23 & 3.22 & 3.27 & 3.37 & 3.38 & $3.167^{\mathrm{b}}$ \\
\hline $\mathrm{T}_{3}(50: 50)$ & 3.23 & 3.26 & 3.27 & 3.34 & 3.42 & 3.46 & 3.47 & 3.63 & $3.38^{\mathrm{a}}$ \\
\hline $\mathrm{T}_{4}(25: 75)$ & 2.72 & 2.73 & 2.76 & 2.82 & 2.85 & 2.92 & 2.94 & 2.95 & $2.84^{\mathrm{c}}$ \\
\hline $\mathrm{T}_{5}(0: 100)$ & 1.42 & 1.46 & 1.51 & 1.53 & 1.56 & 1.61 & 1.67 & 1.70 & $1.56^{\mathrm{d}}$ \\
\hline Day avg. & $2.68^{\mathrm{c}}$ & $2.71^{\mathrm{c}}$ & $2.77^{\mathrm{bc}}$ & $2.86^{\mathrm{abc}}$ & $2.88^{\mathrm{abc}}$ & $2.94^{\mathrm{ab}}$ & $2.98^{\mathrm{a}}$ & $3.02^{\mathrm{a}}$ & \\
\hline
\end{tabular}

LSD value $(p=0.05)$ : day*treatment $=0.449 ;$ treatment $=0.159 ;$ day $=0.201$.

Table 3. Overall results reflected that total phosphorus increased linearly from 0 to 105 days, respectively. Lowest $\mathrm{P}$ levels were recorded in all treatments at the start of composting process. Maximum total phosphorus concentration $(0.81 \%)$ was recorded in treatment $\mathrm{T}_{3}$ however, minimum concentration $(0.51 \%)$ was observed in treatment $\mathrm{T}_{5}$. Rodriguez et al. (2000) also reported an increase in total P level from $0.98 \%$ to $1.96 \%$ while, composting barley waste with solid poultry manure. Increase in the $\mathrm{P}$ concentration is also recorded from the vermi-composting of poultry manure (Kwansod, 2003). Cooperband et al. (1996) also consistently reported maximum $\mathrm{P}$ concentration in mature compost while co-composting poultry litter with different wastes.
Total potassium concentration. The results pertaining to total potassium in co-composting of poultry litter and fast food waste is depicted in Table 4. The results revealed that all the treatments differed significantly from one another with the increasing days of composting. Increase in the potassium concentration was observed from 0 to 105 days of co-composting process. On $105^{\text {th }}$ day, maximum concentration of total K (3.4\%) was found in $\mathrm{T}_{3}$ whereas minimum was found in $\mathrm{T}_{5}(1.67 \%)$. Maximum concentration of total $\mathrm{K}$ in $\mathrm{T}_{3}$ was due to higher microbial activity of composting material. Lowest concentration of total $\mathrm{K}$ in $\mathrm{T}_{5}$ was due to presence of high carbohydrate and low nutrient levels. Chaudhry et al. (2013) also reported increase in the K concentration

Table 3. Comparative effect of co-composting of PL and FFW on concentration of total phosphorus (\%)

\begin{tabular}{|c|c|c|c|c|c|c|c|c|c|}
\hline \multirow{2}{*}{$\begin{array}{l}\text { Treatment } \\
\text { (PL:FFW ratio) }\end{array}$} & \multicolumn{8}{|c|}{ Total $\mathrm{P}$ concentration (days) } & \multirow[t]{2}{*}{ Average } \\
\hline & 0 & 15 & 30 & 45 & 60 & 75 & 90 & 105 & \\
\hline $\mathrm{T}_{1}(100: 0)$ & 0.61 & 0.62 & 0.63 & 0.67 & 0.67 & 0.67 & 0.68 & 0.70 & $0.66^{\mathrm{b}}$ \\
\hline $\mathrm{T}_{2}(75: 25)$ & 0.51 & 0.55 & 0.60 & 0.67 & 0.70 & 0.71 & 0.72 & 0.73 & $0.65^{b}$ \\
\hline $\mathrm{T}_{3}(50: 50)$ & 0.55 & 0.58 & 0.65 & 0.66 & 0.73 & 0.76 & 0.78 & 0.81 & $0.69^{\mathrm{a}}$ \\
\hline $\mathrm{T}_{4}(25: 75)$ & 0.43 & 0.48 & 0.54 & 0.52 & 0.57 & 0.63 & 0.65 & 0.70 & $0.56^{\mathrm{c}}$ \\
\hline $\mathrm{T}_{5}(0: 100)$ & 0.37 & 0.39 & 0.42 & 0.43 & 0.48 & 0.47 & 0.50 & 0.51 & $0.45^{\mathrm{d}}$ \\
\hline Day avg. & $0.49^{\mathrm{d}}$ & $0.52^{\mathrm{d}}$ & $0.57^{\mathrm{c}}$ & $0.59^{\mathrm{c}}$ & $0.63^{\mathrm{b}}$ & $0.65^{\mathrm{b}}$ & $0.67^{\mathrm{ab}}$ & $0.69^{\mathrm{a}}$ & \\
\hline
\end{tabular}

LSD value $(p=0.05)$ : day*treatment $=0.086$; treatment $=0.030$; day $=0.0385$.

Table 4. Comparative effect of co-composting of PL and FFW on concentration of total potassium (\%)

\begin{tabular}{|c|c|c|c|c|c|c|c|c|c|}
\hline \multirow{2}{*}{$\begin{array}{l}\text { Treatment } \\
\text { (PL:FFW ratio) }\end{array}$} & \multicolumn{8}{|c|}{ Total $\mathrm{K}$ concentration (days) } & \multirow[t]{2}{*}{ Average } \\
\hline & 0 & 15 & 30 & 45 & 60 & 75 & 90 & 105 & \\
\hline $\mathrm{T}_{1}(100: 0)$ & 2.81 & 3.00 & 3.12 & 3.17 & 3.21 & 3.26 & 3.29 & 3.28 & $3.41^{\mathrm{a}}$ \\
\hline $\mathrm{T}_{2}(75: 25)$ & 2.27 & 2.37 & 2.62 & 2.74 & 2.79 & 2.88 & 2.93 & 2.96 & $2.69^{\mathrm{b}}$ \\
\hline $\mathrm{T}_{3}(50: 50)$ & 1.34 & 1.37 & 1.85 & 2.50 & 2.75 & 2.90 & 3.33 & 3.40 & $2.43^{\mathrm{c}}$ \\
\hline $\mathrm{T}_{4}(25: 75)$ & 1.16 & 1.22 & 2.03 & 1.72 & 2.03 & 2.14 & 2.20 & 2.22 & $1.77^{\mathrm{d}}$ \\
\hline $\mathrm{T}_{5}(0: 100)$ & 0.82 & 0.86 & 1.00 & 1.29 & 1.42 & 1.58 & 1.60 & 1.67 & $1.28^{\mathrm{e}}$ \\
\hline Day avg. & $1.68^{\mathrm{f}}$ & $1.76^{\mathrm{cf}}$ & $2.01^{\mathrm{e}}$ & $2.30^{\mathrm{e}}$ & $2.44^{\mathrm{c}}$ & $2.55^{\mathrm{b}}$ & $2.67^{\mathrm{a}}$ & $2.71^{\mathrm{a}}$ & \\
\hline
\end{tabular}

LSD value $(\mathrm{p}=0.05)$ : day*treatment $=0.194$; treatment $=0.069$; day $=0.087$. 
in the mature composts. Clark (2000) found K levels in similar ranges in food waste composting and associated $\mathrm{K}$ increase with the microbial activity.

\section{Conclusion}

In the present research, co-composting of poultry litter and fast food waste was carried out in different combinations. Among different ratios of composts prepared and analysed for the nutrient dynamics, maximum concentration of total nitrogen (3.63\%), total phosphorus $(0.81 \%)$, and total potassium $(3.40 \%)$ were found in the mature compost of $\mathrm{T}_{3}$ (containing equal proportion of poultry litter and fast food restaurant waste). Carbon to nitrogen ratio $(18.33 \%)$ for this treatment $\left(\mathrm{T}_{3}\right)$ was also suitable to promote better plant growth. Temperature remained effectively high in $\mathrm{T}_{3}\left(6-16{ }^{\circ} \mathrm{C}\right.$ higher as compared to the rest of the treatments) which supported strong microbial activity in this treatment leading to enhanced levels of studied nutrients $(\mathrm{N}, \mathrm{P}, \mathrm{K})$ and lower $\mathrm{C}: \mathrm{N}$ ratio. This investigation supports the utilization of co-composting of poultry litter and fast food waste to enhance nutrient concentrations in the mature compost as compared to the other combinations studied. Usage of co-compost resulting from the combination $\left(\mathrm{T}_{3}\right)$ can effectively improve soil health, fertility and nutrient availability resulting in better plant growth and avoiding phytotoxic effects.

\section{References}

Ali, Z., Ali, B., Mohammad, A., Ahmad, M., Ahmad, I., Napar, A.A., Kazi, A.G., Ali, A., Shah, S.S., Mujeeb-Kazi, A. 2013a. Combating water scarcity for global food security. In: Agricultural Systems in the $21^{\text {st }}$ Century, A. Raza (ed.), pp. 1-30, Nova Science Publishers, Hauppauge, NY, USA.

Ali, Z., Malik, R.N., Qadir, A. 2013b. Heavy metals distribution and risk assessment in soils affected by tannery effluents. Chemistry and Ecology, 29: 676-692.

Adhikari, B.K., Barrington, S., Martinez, J., King, S. 2008. Characterization of food waste and bulking agents for composting. Waste Management, 28: 795-804.

Alburquerque, J.A., Gonzalvez, J., Grcia, D., Cegarra, J. 2006. Composting of solid olive-mill product and the potential of the resulting compost for cultivating pepper under commercial conditions. Waste Management, 26: 620-626.

Benito, M., Masaguer, A., Moliner, A., Antonio, R. 2006. Chemical and physical properties of pruning waste compost and their seasonal variability. Bioresource Technology, 97: 2071-2076.

Bremner, J.M. 1996. Nitrogen and Total Phosphorus. In: Methods of Soil Analysis. Part 3-Chemical Methods, D. I. Sparks (ed.), pp. 1085-1122, SSSA and ASA, Madison, WI, USA.

Cambardella, C.A., Richard, T.L., Russell, A. 2003. Compost mineralization in soil as a function of composting process conditions. Eurasian Journal of Soil Biology, 39: 117-127.

Castaldi, P., Garau, G., Melis, P. 2008. Maturity assessment of compost from municipal solid waste through the study of enzyme activities and watersoluble fractions. Waste Management, 28: 534540.

Chang, J.I., Tsai, J.J., Wu, K.H. 2006. Thermophilic composting of food waste. Bioresource Technology, 97: 116-122.

Chaudhry, A.N., Naeem, M.A., Jilani, G., Razzaq, A., Zhang, D., Azeem, M., Ahmed, M. 2013. Influence of composting and poultry litter storage methods on mineralization and nutrient dynamics. Journal of Animal and Plant Sciences, 23: 500-506.

Clark, S. 2000. Development of a Biologically Integrated Food Waste Composting System. Vol. 1, pp. 1-8, Berea College, Kentucky, USA.

Cooperband, L., Middleton, R. June, H. 1996. Changes in chemical, physical and biological properties of passively aerated co-composted poultry litter and municipal solid waste compost. Compost Science and Utilization, 4: 24-34.

ESP, 2010. Pakistan Economic Survey 2009-10; pp. 2930, Finance Division E.A. Wing Government of Pakistan, Printing Corporation, Pakistan Press, Pakistan.

Esse, P.C., Buerkert, A., Hiernaux, P., Assa, A. 2001. Decomposition of and nutrient release from ruminant manure on acid sandy soils in the Sahelian zone of Niger, West Africa. Agriculture Ecosystem and Environment, 83: 55-63.

Goyal, S., Dhull, S.K., Kapoor, K.K. 2005. Chemical and biological changes during composting of different organic wastes and assessment of compost maturity. Bioresource Technology, 96: 1584-1591.

Iyengar, S.R., Bhave, P.P. 2006. In-vessel composting of household wastes. Waste Management, 26: 10701080 .

Khan, M.A., Rahim, M., Ali, S. 2003. Sewage sludge effect on soil fertility of maize as compared to poultry litter, farmyard manure, and chemical 
fertilizer. Pakistan Journal of Agricultural Sciences, 6: 69-77.

Kuo, S. 1996. Phosphorus. In: Methods of Soil Analysis, Part 3-Chemical Methods, D.I. Sparks (ed.), pp. 869-919, SSSA and ASA. Madison, WI, USA.

Kwansod, T. 2003. Treatment and Vermicomposting of Chicken Manure using Lumbricus rubellus and Eudrilus eugeniae. Master of Science (Agriculture). Department of Animal Science, Kasetsart University, Bangkok. Thailand.

Nelson, D.W., Sommers, L.E. 1982. Total carbon, organic carbon and organic matter. In: Methods of Soil Analysis, Part II, A.L. Page (ed.), pp. 539-579, American Society of Agronomy, Madison, USA.

Ranalli, G., Battura, G., Taddei, P., Garavani, M., Marchetti, P., Sorlini, C. 2001. Composting of solid and sludge residues from agricultural and food industries. Bioindicators of monitoring and compost maturity. Journal of Environmental Science and Health. Part A, Toxic/hazardous Substances and Environmental Engineering, 36: 415-436.

Rodriguez, G.E., Vazquez, M., Ravina, M.D. 2003. Dynamics of the co-composting of barley waste with liquid poultry manure. Journal of the Science of Food and Agriculture, 83: 166-172.

Rodriguez, G.E., Vazquez, M., Ravina, M.D. 2000. Cocomposting of barley wastes and solid poultry manure. Bioresource Technology, 75: 223-225.

Tiquia, S.M., Wan, J.H.C., Tam, N.F.Y. 2001. Extracellular enzyme profiles during co-composting of poultry manure and yard trimmings. Process Biochemistry, 36: 813-820.

Zhang, X.W., Wang, H., Nie, H.Y., Qiu, X. 2003. Cocomposting of high moisture vegetable waste, flower waste and chicken litter in pilot scale. Huan Jing Ke Xue, 24: 32-37. 